\title{
Employees Work Stress Level in the Hospital
}

\author{
Lolyta Aditya Puteri, Muhammad Irfan Syaebani
}

Department of Management, Faculty of Economics and Business, Universitas Indonesia, Jl. Prof. Dr. Sumitro Djojohadikusumo, UI Depok 16424

\begin{tabular}{|c|c|}
\hline ARTICLE INFO & A B S T R A C T \\
\hline $\begin{array}{l}\text { Keywords: } \\
\text { job stress survey; } \\
\text { work stress; } \\
\text { employee work stress; } \\
\text { hospital; } \\
\text { health professional } \\
\text { Kata Kunci: } \\
\text { survey stres kerja, } \\
\text { stres kerja, } \\
\text { stres kerja karyawan, } \\
\text { rumah sakit, } \\
\text { pekerja kesehatan }\end{array}$ & $\begin{array}{l}\text { Workers in the health industry are more likely having a higher level } \\
\text { of stress compare to other professions in other sectors. Work stress } \\
\text { impacts adverse consequences such as fatigue, absenteeism, turnover, } \\
\text { customer dissatisfaction, and for health professionals, in particular, it } \\
\text { will lead to incorrect diagnosis and curative action. The study aims } \\
\text { to identify the source of stress in the hospital among three divisions; } \\
\text { medical professional, medical support, and general support as a case } \\
\text { study to } 181 \text { employees at a hospital in Depok city. Job stress survey } \\
\text { (JSS) is selected to measure employee work stress based on three } \\
\text { indicators: job stress, job pressure, and lack of organisational support. } \\
\text { Job stress survey maps the severity of stress, the frequency of stress, } \\
\text { and the index of stress for all those three indicators. The research } \\
\text { design is quantitative and uses analysis of variance (ANOVA) to test } \\
\text { the different level of stress among three divisions. The result indicates } \\
\text { the level of stress is different among three divisions based on stress } \\
\text { severity. However, the difference is insignificant on stress frequency } \\
\text { and stress index on two indicators namely job pressure and lack of } \\
\text { organisational support. Among three divisions, professional medical } \\
\text { workers experience the highest level of stress. The implication of the } \\
\text { research is discussed. }\end{array}$ \\
\hline
\end{tabular}

Corresponding author: muhammad.irfan11@ui.ac.id

\section{SARI PATI}

Pekerja di industri kesehatan memiliki kencenderungan tingkat stress yang tinggi dibandingkan pekerja di industri yang lain. Stres di tempat kerja memberikan dampak yang buruk seperti kelelahan, mangkir kerja, perpindahan, ketidakpuasaan konsumen, dan khusus untuk pekerja bidang medis stress kerja dapat menyebabkan kekeliruan diagnosis dan perawatan. Penelitian ini bertujuan untuk mengidentifikasi sumber stress di rumah sakit dari tiga divisi; medis, pendukung medis, dan pendukung umum sebagai sebuah studi kasus dari 181 pekerja di sebuah rumah sakit di kota Depok. Instrumen pengukuran menggunakan job stress survey atau JSS yang mengukur tingkat stress berdasarkan tiga indikator; stres kerja, tekanan kerja, dan 
kurangnya dukungan organisasi. JSS memetakan tingkat keparahan, frekuensi, dan indeks stress dari ketiga indikator tersebut. Desain riset adalah kuantitatif dan menggunakan tes ANOVA untuk mengukur perbedaan tingkat stress di antara ketiga divisi. Hasil penelitian menunjukkan bahwa tingkat keparahan stress berbeda antara satu divisi dengan yang lainnya. Akan tetapi, tidak terdapat perbedaan yang signifikan antara frekuensi dan indeks stress di dua indikator yaitu job pressure dan lack of organisational stress. Di antara ketiga divisi, pekerja di divisi medis memiliki tingkat stres kerja tertinggi. Implikasi penelitian dipaparkan juga di dalam artikel ini.

(C) 2018 IRJBS, All rights reserved.

\section{INTRODUCTION}

Stress stems from the relation between a person and the surrounding environment. Stress is an unpleasant emotional situation. In the working sphere, stress appears when an employee experiences unbalance situation between work demand and the ability to manage it. Severe work stress could result in adverse consequences to individual health both mental and physical (Health and Safety Executive, 2001; Cooper et al., 2001 in Ibrahim 2014). Globally, the cost related to work stress reached $\$ 5.4$ billion per year in estimation (Health and Safety Executive, 2010 in Salilih and Abajobir 2014). Work stress also affects the quality of life including social relationship and family life. Many reports admit work stress induces absenteeism, turnover, reduced productivity and feebleservice (European Foundation for the Improvement of Living and Working Conditions, 2007; Health and Safety Executive, 2011 in Salilih and Abajobir 2014).

Lately, work stress has captured thoroughscrutiny from many researchers (Fisher, 2001; Bernardi, 1997; Patten, 1995; Choo, 1987 in Ibrahim 2014). Sauter et al., (1999) in Ibrahim (2014) defined work stress as severe physical and emotional response and happen when there is a discrepancy between work demand with the capabilities, the resources, or the need of employees. Work stress also could be described as awareness or impression that an employee perceives as the impact of condition or event appeared in the workplace. Work stress is a psychological and physiological reaction because of an unpleasant feeling, unwanted experience, or direct threat (Montgomery et al., 1996 in Ibrahim 2014). Karasek and Theorell (1990 in Holmstrom, Molander, Jansson, and Bergqvist, 2008) argued work stress directly affects higher absenteeism and turnover and in the long run it will heighten economic cost of the organisation, thus it is very crucial for every organisation to identify the source and the frequency of stress of the employees.

The antecedents of work stress could be classified into four dimensions; role ambiguity, role conflict, excessive workload, and scarcity of resources (Rizzo, House, \& Lirtzman, 1970 in Ibrahim 2014). Work stress is a physical and emotional response from the employees to indicate their inability to cope with work demand (Malik, 2011 in Ibrahim 2014). If the work stress is improperly managed, it may drive to a higher risk of destruction for both employee and organisation.

Work stress has captured attention in the health industry since profession in this industry is more likely to be exposed in work stress (Franco, Bennet \& Kanfer, 2002; WHO 2000 in Obasohan $\&$ Ayodele, 2014). The study demonstrated health 
professionals have a high-level probability of drug abuse and contemplating suicide compared to other professions (National Institute for Occupational Safety and Health, 2009 in Obasohan \& Ayodele, 2014).High level of depression and anxiety are also as a common phenomenon among health professionals.People who work in the health industry, especially in the hospital, will yield negative impact if they are under stress. The brunt is not only for themselves but also for the people under their treatment and it is not limited only to the medical staff but also to all crews in the hospital since the nature of work in hospital requires cooperation from all divisions (Gundersen, 2001; Grunfeld et al., 2000 in Pisljar, Lippe, and Dulk 2011). Beside workload and time pressure, people who work in hospital must perform direct contact with patients on daily basis and it could be a source of stress because sometimes patients are already depressed with their conditions, and it becomes unfavorable emotional contagion (Grunfeld et al., 2000 in Pisljar, Lippe, and Dulk 2011).

Moreover, doctors and nurses are exposed to the risk of contamination if they disregard standard procedures which sometimes hard to follow especially in an emergency situation. The society is also adding the burden to the people who work in a hospital since they are expected to be able to cure any conditions experienced by the patients as if they were playing God.If the work stress is unable to manage wisely, the patients are under threat because the medical professional might perform wrong handling.

Azwar (1996) stated hospital is a centre where it addresses health service to the community, and it also has a strategic role in raising public health level. The level of public health is an indicator of the prosperity of a country. Therefore, hospitals are required to deliver service with the high standard of quality and serve it to the public without exception. Every hospital must ensure that all workers are in the excellent circumstances to render minimum quality standard, including the stress level. A hospital should guarantee that work stress of the employees is manageable.

Experts defined stress as a balance disruption of a cognitive, emotional, and environmental system which is generated by external factors (Lazarus and Folkman, 1984 in Jannoo, Wah, and Haron 2014). Stress also refers to how an individual cast a reaction to every challenge and crisis. It is widely believed that environment plays a vital role in producing stress of a person. Mostert et al. (2008) in Jannoo, Wah, and Haron (2014) classified stress into three different groups; (1) stress based on the stimulus, (2) stress based on the response, and (3) stress based on the interaction of the stressor. Stress based on stimulus explainsstress as the effect of external situation and environment to the individual. Stress based on response defined stress merely as a psychological and physiological response of an individual in responding to various occasions, it means internal aspect of a person causes stress. Stress based on the interaction of the stressor emphasised stress as a combination of external effect or the environment and internal response of individual or reaction of an individual. It explains although an individual received the similar external stimulus, the response of an individual to that stimulus may differ. It is because stress is a combination of the external stressor and internal response. Many people experienced the adverse reaction of stress such as drug abuse (Richmond et al. 1999; Vasse et al. 1998 in Jannoo, Wah, and Haron 2014) and social problems (Thoits 1995 in Jannoo, Wah, and Haron 2014).

Stress generates an emotional, physical, social, and economical response which stipulates adjustment to neutralise the pressure (Alberta, 2008 in Agyemang, Nyanyofio, and Gyamfi, 2014). Work stress arises because of interaction between workers during the working period (Durand, 2003 in Agyemang, Nyanyofio, and Gyamfi, 2014). Work stress may occur when the employees are unable to cope with working demand, and it creates psychological burdens (Edwards, 2003 in 
Nowrouzi et al., 2015). Work stress is a problem for both the employees and the organisations; if it was managed improperly, it might result in harmful consequences for the sustainability of the organisation. Work stress also will hamper organisation in recruiting and retaining talented employees (Bartram, Joiner, and Stanton, 2004 in Nowrouzi et al., 2015). Work-related issues might cause the tension in the workplace. However, personal problems also could impact the employees well being (Zeller and Levin, 2013 in Nowrouzi et al., 2015). Many experts agreed that individual and organisational stressor as the antecedents of work stress (Cooper, C.L., Marshall, J. 1976 in Lu, Liu, Sui, and Wang, 2015). Incapability to balance the work demand is attributed as the primary factor of stress, but the study also found that inequity between work effort and reward supports a significant role in creating work stress (Karasek, R.A. 1979, Seigrist, J. 1996 in Lu, Liu, Sui, and Wang, 2015). If work demand is unmatched with the employees' ability and need or availability of resources is lack, work stress will become a perilous matter in the futurefor both parties (National Institute for Occupational Safety and Health, 1999 in Habibi et al., 2014). In short, work stress happens when a stressor is more prominent than individual ability in a coping mechanism. Many studies blamed burnout as the cause of stress. The excessive workload is reported in many work stress cases (Hanrahan et al., 2010 in Thian, Kannusamy, Gu, and Yobas, 2015). Many organisations nowadays become concern about work stress as indicated by the growing number of medical and psychological literature which discusses the issue in last 25 years (Holmstrom, Molander, Jansson, and Bergqvist 2008).

Individual disposition plays a significant role in determining stress levelbecause different people may demonstrate response differently to the similar stressor. However, all the employees agreed albeit there is a different way in responding stressor works demand is one of the factors to blame in the workplace (Luk, 2009 in Agyemang,
Nyanyofio, and Gyamfi, 2014). Working condition such as sound, light, temperature, work shift, work hour, commuting, new technology, and workload are the antecedents of work stress. Many organisations adopt to implement work redesign as a strategy to prevent the occurrence of work stress (Luk, 2009 in Agyemang, Nyanyofio, and Gyamfi, 2014). Refer to thearticle of Holmstrom, Molander, Jansson, and Bergqvist (2008) organisation can measure the stress level of the employees from three indicators; there are (1) job stressor, (2) strain, and (3) health outcomes. Job stressor refers to the working condition which may affect stress directly. Strain refers to the psychological and physiological response that employee's exhibit to a specific exposureand health outcomes related to the adverse health condition of employees because of stress. Many organisations use those three indicators as a signal to measure stress level. If the job stressors are many, strains are harmful, and employees show lousy health condition it is an indication that work stress attacks the organisation and immediate actions should be taken.

The high level of stress leads to an adverse effect on the performance of workers (Jannoo, Wah, and Haron, 2014). According to Himabindu and Syed (2013) impact of stress can be classified into three categories:(1) physiological effects including higher blood pressure, faster heartbeat, excessive sweating, headache, insomnia, fever, respiratory problem, muscle ache, and eating problem, (2) emotional effects including anxiety, anger, depression, loneliness, guilty feeling, unhappiness, lack of confident, and dissatisfaction, and (3) behavioral effects including impatient, hyperactivity, alcohol and drug abuse, absenteeism, turnover, working error, and inadequate communication. Working stress is a severe threat to people who work in the health industry since they are responsible for providing health care and if the service is disturbed, it will put people under risk. Working stress could produce aggression and misbehaviour at work, and it directly affects work productivity (Mosadeghrad, 
Ferlie, \& Rosenberg, 2011 in Nowrouzi et al. 2015). Karasek and Theorell (1990) in Holmstrom, Molander, Jansson, and Bergqvist (2008) argued that work stress mostly causes the increasing number of absenteeism and turnover. Work stress is a general term to define a process of adaptation where the process resulted in psychological distress (Jamal and Baba 2000; Rothmann et al. 2003 in Jannoo, Wah, and Haron 2014). Prolonged exposure to work stress can increase the likelihood of heart problem (European Foundation for the Improvement of Living and Working Conditions, 2007 in Salilih and Abajobir 2014) and weaken the immune system (Health and Safety Executive, 2011 in Salilih and Abajobir 2014). Stress could impact the quality of life, well being, social, and family life. Many reports said stress led to a high number of turnovers and resulted in the adverse outcome to health delivery provided by health service centres (Department of Health and Children, 2002 in Salilih and Abajobir, 2014). Several reports admitted stress as one of the sources of working hazard, and it might threaten psychological well being, physical health, work performance, and job satisfaction (Cooper, Marshall, 1976; Parker, DeCotiis, 1983 in Lu, Liu, Sui, and Wang, 2015). Many records reported work stress as the primary factor which negatively affected employees' job satisfaction in many industries (Kuo, 2015 in Lu, Liu, Sui, and Wang, 2015).

In the last years, empirical studies focused on detrimental effects of work stress since it is widely believed that unmanaged work stress only gives disadvantageous impact to employee and organisation. Studies found employees who work in the shift will likely to have a higher level of stress (Harrington, 2001; Shields 2006 in Obasohan and Ayodele 2014). Occupational Health Clinics for Ontario Workers (2005 in Obasohan \& Ayodele, 2014) stated employees who work in shift might experience socialisation problem with family and friend, and unable to partake in social activities because of an unusual working hour. Work in shift may causecircadian rhythm problem, declining quality of sleeping, fatigue, anxiety, depression, and neuroticism (Harrington 2001 in Obasohan and Ayodele 2014).

Globally, people who work in health service are considered as the most stressful profession (Franco, Bennet \& Kanfer, 2002; WHO 2000 in Obasohan and Ayodele 2014). Work processes in health industry often full of the stressor and it required people who work in it to be alert all the time. National Institute for Occupational Safety and Health (2009 in Obasohan and Ayodele, 2014) stated work stress becomes the issue in many health service providers and researches from many developed countries showed people who work in the health industry are in higher risk of drug abuse, suicide, depression, and anxiety compare to other professions.

Wu, Zhao, and Wang (2006) in Hu, Wang, Xu, and $\mathrm{Xu}$ (2014) reported medical workers have a high level of stress and it is a common phenomenon among health professional. Work stress in medical workers is critical to managing since it will give negative impact to quality of work and strongly related with mental health (Abu Al-Rub and $\mathrm{Al}$ Zaru, 2008; Ma, Yue, Zhou, and Huang, 2013 in Hu, Wang, $\mathrm{Xu}$, and $\mathrm{Xu} 2014$ ).

Employees who work in the hospital such as the doctor, nurse, and supporting professionals are exposed to stress problem. If it is not appropriately managed, it will affect not only the employees but also the patients (Gundersen, 2001; Grunfeld et al., 2000 in Pisljar, Lippe, and Dulk, 2011). Beside work demand, people who work in the hospital may expose to negative emotion from patients. Emotional contagion is real if workers regularly interact with people who might experience depression because of the disease they have (Grunfeld et al., 2000 in Pisljar, Lippe, and Dulk 2011). Doctor and nurse who handle unusual emergency situation may be exposed to infectious disease from patients, but they are obliged to perform medical treatment whatsoever. 
Work stress will cause performance deficiency, poor quality delivery, higher risk of infectious exposure in the hospital, and diminishing patient's satisfaction (Cimiotti et al., 2012; Nat et al., 2011 in Thian, Kannusamy, Gu, and Yobas, 2015). Work stress also related with organisational culture, lousy leadership, ineffective corporate structure, career dissatisfaction, work insecurity, unfair evaluation system, monotonous working activity, and lack of social support (Leka et al., 2003 in Thian, Kannusamy, Gu, and Yobas, 2015). An interpersonal conflict also contributes to work stress and if it poorly handled it will raise the plausibility of medical malpractice (Baldwin and Daugherty, 2008 in Thian, Kannusamy, Gu, and Yobas, 2015).

\section{METHODS}

\section{Job Stress Survey}

There are several approaches to assess level of stress of the employees such as; direct observation, production measurement, self-report, interview, and stress measurement tool likeJob Content Questionnaire (Karasek, 1985 in Holmstrom, Molander, Jansson, and Bergqvist, 2008), Job Diagnostic Survey (Hackman and Oldham, 1975 in Holmstrom, Molander, Jansson, and Bergqvist 2008), Job Stress Survey (Spielberger and Vagg, 1999 in Holmstrom, Molander, Jansson, and Bergqvist 2008), Occupational Stress Indicator (Cooper, Sloan, and Williams, 1988 in Holmstrom, Molander, Jansson, and Bergqvist 2008), Occupational Stress Inventory (Osipow and Spokane, 1987 in Holmstrom, Molander, Jansson, and Bergqvist 2008), Pressure Management Indicator (Williams and Cooper, 1998 in Holmstrom, Molander, Jansson, and Bergqvist 2008) andQPSNordic (Dallner et al., 2000 in Holmstrom, Molander, Jansson, and Bergqvist 2008). However, job stress survey or JSS (Spielberger and Vagg 1999 in Jannoo, Wah, and Haron 2014) is the most comprehensive tool to depict perception of work stress (Brewer and McMahan 2003; Holmstrom et al 2008; Rothman et al 2003; Turnage and Spielberger 1991; Vagg et al. 2002 in Jannoo, Wah, and Haron 2014). Many tools barely emphasised on agreement and disagreement level of stressor from the respondents. Spielberger (1983 in Holmstrom, Molander, Jansson, and Bergqvist, 2008) argued that in measure work stress it is vital to capture the severity of stress and the frequency of occurrence because those two factors are critical to determining how severe the employees are experiencing stress at work. Spielberger and Vagg (1999 in Holmstrom, Molander, Jansson, and Bergqvist 2008) claimed if the frequency of stress is not accounted it will focus only on the stressor although that stressor is unlikely to happen in the daily activities of the employees.

Job stress survey is designed to elaborate on the source of stress in various working conditions (Spielberger, 1991; Spielberger and Vagg, 1999 in Jannoo, Wah, and Haron, 2014). Every item in JSS describes the general event in the job. JSS investigates the severity of the stressor and how often that stressor happens in the last six months. JSS consists of 30 items questions, and it elaborates stressor event related to many working conditions. Items in JSS focused on the situational aspect that the workers usually encounter on a daily basis which may lead to psychological distress. Respondents will rate the severity level and the frequency of every situational aspect which considered asa stressor.When filling in JSS items, respondents will assess the severity level on nine Likert points where one is low stress, and nine is high stress. After finished rating severity level, respondents will fill in of how often the 30 stressor events manifest in the last six months using ten scales where 0 is never happening, and nine is nine times occur in the previous six months. From the severity level and the frequency level, it will create stress index level. Stress index level is the outcome of multiplication of severity and frequencyin the range from 0 to 81 where 0 is the lowest stress index, and 81 is the highest stress index (Jannoo, Wah, and Haron 2014).

The instrument of JSS consists of three stress scale which is: job stress severity (JS-S), job stress 
frequency (JS-F), and job stress index (JS-X), and six sub-scales from 30 stressor events. JS-S showed average level of stress severity felt by the respondents, JS-F showed the frequency of stressors are likely to happen in the last six months, and JS-X is the multiplication between JS-S and JS-F to show the whole index of work stress.

JSS has six sub-scales which are created by factor analysis based on the item with high loading factor score. Those six sub-scales are classified into two main factors namely Job Pressure and Lack of Organisational Support (Spielberger and Vagg, 1999 in Holmstrom, Molander, Jansson, and Bergqvist, 2008). Job pressure is divided into three; severity (JP-S), frequency (JP-F), and index (JP-X) and the division is similar for lack of organisational support. It has three categories; severity (LS-S), frequency, (LS-F), and index (LS-X).

Job stress in JSS is defined as a physical and emotional response which may impair the employees in the event where work demand is unmatched with ability and resource (National Institute for Occupational Safety and Health, 1999 in Habibi et al., 2014). Job stress describes general stressor in the workplace. Job pressure in JSS is explained as work requirement that an employee must stand or adhere when he/she performs the job, and it may cause specific psychological and physiological problems (Rothmann et al. 2003 in Jannoo, Wah, and Haron, 2014). Lack of organisational support refers to the corporate condition where it provides less support in fulfilling socio-economical needs of the employees, lack in supporting employees' effort in doing the job, and do not value employee's commitment and loyalty. Organisational support includes support from supervisor, co-workers, and surrounding environment (Spieldberger et al., 2003 in Jannoo, Wah, and Haron, 2014).

\section{Population and Sample}

Population in this study is all employees who work in medical division, medical support division, and general support division in a hospital in the city of Depok. The total of employees is 340 , and according to sample size rule of thumb, the sample to collect is 181 employees (Krejcie and Morgan, 1970 in Sekaran, 2003). The samples are taken proportionally where $40 \%$ of samples are employees from the medical division, 18\% of samples are employees from medical support division, and $42 \%$ of samples are employees

Tabel 1. Scales and Sub-scales of Job Stress Survey

\begin{tabular}{|c|c|c|}
\hline \multicolumn{3}{|c|}{ Severity of Stress } \\
\hline JS-S & JP-S & LS-S \\
\hline $\begin{array}{c}\text { Job stress measurement based } \\
\text { on the severity level from } 30 \\
\text { stressor events }\end{array}$ & $\begin{array}{c}\text { Job pressure measurement based } \\
\text { on the severity level from } 30 \\
\text { stressor events }\end{array}$ & $\begin{array}{l}\text { Lack of organisational support } \\
\text { measurement based on the severity } \\
\text { level from } 30 \text { stressor events }\end{array}$ \\
\hline \multicolumn{3}{|c|}{ Frequency of Stress } \\
\hline JS-F & JP-F & LS-F \\
\hline $\begin{array}{c}\text { Job stress frequency in the last } \\
\text { six months from } 30 \text { stressor } \\
\text { events }\end{array}$ & $\begin{array}{l}\text { Job pressure frequency during } \\
\text { the previous six months from } 30 \\
\text { stressor events }\end{array}$ & $\begin{array}{l}\text { Lack of organisational support } \\
\text { frequency during the previous six } \\
\text { months from } 30 \text { stressor events }\end{array}$ \\
\hline \multicolumn{3}{|c|}{ Index of Stress } \\
\hline JS-X & JP-X & LS-X \\
\hline $\begin{array}{l}\text { The result of multiplication } \\
\text { between JS-S and JS-F to } \\
\text { describe general stress index } \\
\text { range from } 0 \text { to } 81\end{array}$ & $\begin{array}{c}\text { The effect of multiplication } \\
\text { between JP-S and JP-F to describe } \\
\text { general stress index range from } \\
0 \text { to } 81\end{array}$ & $\begin{array}{l}\text { The result of multiplication between } \\
\text { LS-S and LS-F to describe general } \\
\text { stress index range from } 0 \text { to } 81\end{array}$ \\
\hline
\end{tabular}


Tabel 2. Validity and Reliability of Measurement of Stress Severity and Frequency

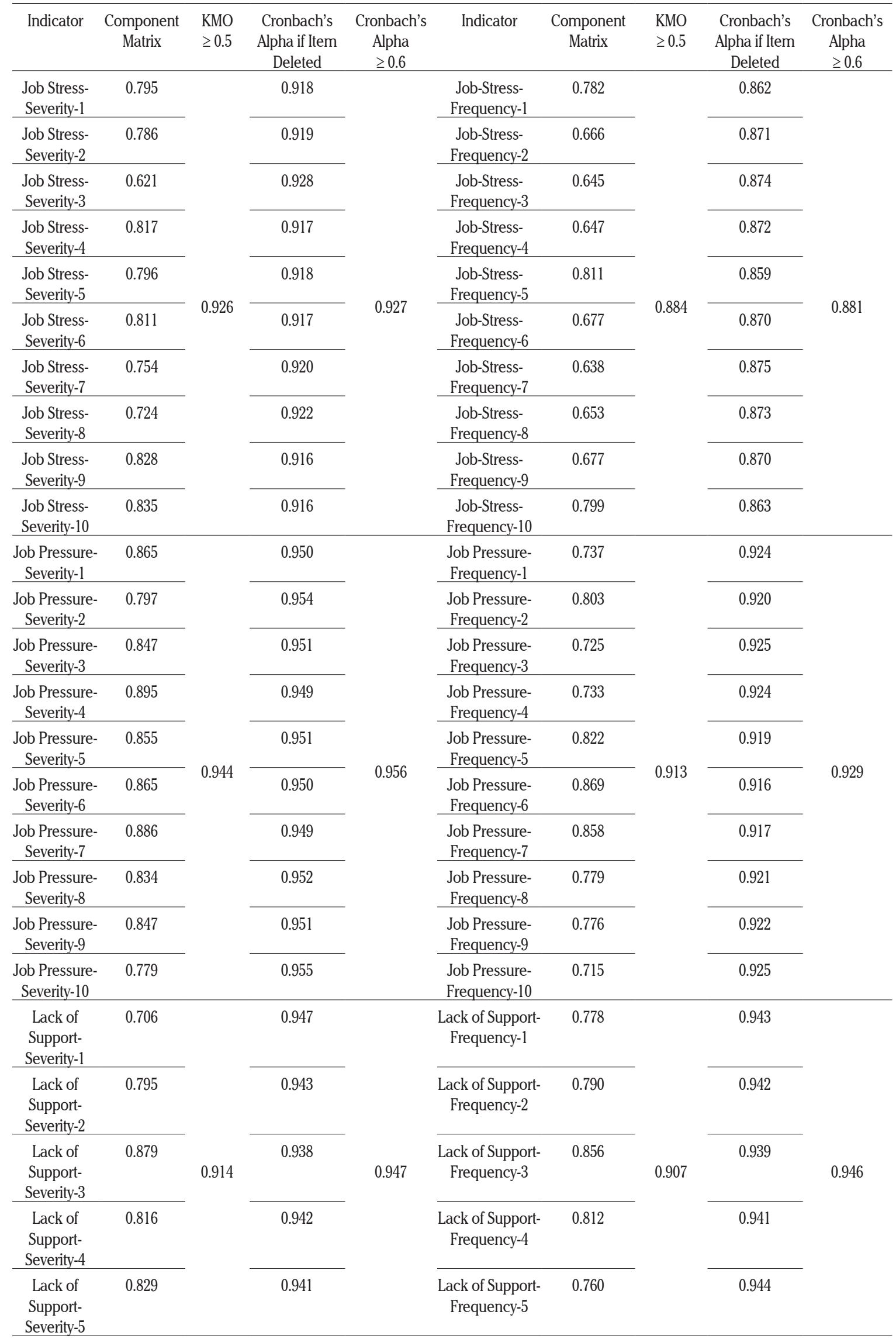




\begin{tabular}{|c|c|c|c|c|c|c|c|c|c|}
\hline $\begin{array}{c}\text { Lack of } \\
\text { Support- } \\
\text { Severity-6 }\end{array}$ & 0.865 & & 0.939 & & $\begin{array}{l}\text { Lack of Support- } \\
\text { Frequency-6 }\end{array}$ & 0.880 & & 0.938 & \\
\hline $\begin{array}{l}\text { Lack of } \\
\text { Support- } \\
\text { Severity-7 }\end{array}$ & 0.834 & & 0.941 & & $\begin{array}{l}\text { Lack of Support- } \\
\text { Frequency-7 }\end{array}$ & 0.872 & & 0.938 & \\
\hline $\begin{array}{l}\text { Lack of } \\
\text { Support- } \\
\text { Severity-8 }\end{array}$ & 0.830 & 0.914 & 0.941 & 0.947 & $\begin{array}{l}\text { Lack of Support- } \\
\text { Frequency-8 }\end{array}$ & 0.894 & 0.907 & 0.937 & 0.946 \\
\hline $\begin{array}{l}\text { Lack of } \\
\text { Support- } \\
\text { Severity-9 }\end{array}$ & 0.837 & & 0.941 & & $\begin{array}{l}\text { Lack of Support- } \\
\text { Frequency-9 }\end{array}$ & 0.838 & & 0.940 & \\
\hline $\begin{array}{l}\text { Lack of } \\
\text { Support- } \\
\text { Severity-10 }\end{array}$ & 0.831 & & 0.941 & & $\begin{array}{l}\text { Lack of Support- } \\
\text { Frequency-10 }\end{array}$ & 0.732 & & 0.944 & \\
\hline
\end{tabular}

from general support division. Since the number of samples is 181 employees, thus at least 72 respondents must be employees in medical division, 32 respondents must be from medical support workers, and 77 respondents from general support division.

Validity and Reliability of Instrument of JSS and Analysis of Variance (ANOVA)

The questionnaire distributed in Bahasa Indonesia and as many as 181 respondents participated in the survey. The validity and reliability of the instrument are presented in table 2. From table 2 , it implied that the tool (JSS) had met the minimum standard of validity and reliability. According to Sekaran (2003) Analysis of Variance or ANOVA is a statistical procedure to test the significant difference between two or more sample groups in interval or ratio scale. ANOVA test shows whether there is any significant difference between one group and another. In this study, the sample is grouped into three based on working division: medical, medical support, and general support. ANOVA test will display whether the stress level between divisions is similar or different.

\section{RESULTS AND DISCUSSION}

\section{Respondents Profile}

The respondent's profiles are demographic data including contact number, working division, tenure, education level, sex, and age. The summary of respondents profile is in table 3 .

\section{Discussion}

According to the mean report which is illustrated in table 4, it concludes that employees who work in the medical division have the highest level of work stress at all scales: severity, frequency and index.All indicators inJSS including job stress, job pressure, and lack of organisational support are scored higher by the employees in the medical division.

It is not surprising since the work demand and time pressure in the medical division is more intricate because it is the critical service in the health industry. People who work in the medical division are also required to have continuous contact with the patients whom sometimes already suffer because of their health condition (Grunfeld et al., 2000 in Pisljar, Lippe, and Dulk 2011). Likewise, employees in the medical division need to be alert all the time in case of the emergency situation takes place and sometimes it creates work burnout (Gundersen, 2001; Grunfeld et al., 2000 in Pisljar, Lippe, and Dulk 2011). Therefore, it is acceptable if employees in the medical division may suffer more severe in stress.

Behind medical division, the employees who work in medical support division have the second high of stress level, and the least stress employees are those who work in general support division. Very much alike with people who work in medical division, employees in medical support 
Tabel 3. Respondents Profile

\begin{tabular}{|c|c|c|c|}
\hline Category & Classification & Frequency & Percentage \\
\hline \multirow{3}{*}{ Working Division } & Medical Professional & 72 & $39.78 \%$ \\
\hline & Medical Support & 32 & $17.68 \%$ \\
\hline & General Support & 77 & $42.54 \%$ \\
\hline \multirow{5}{*}{ Tenure } & $\leq$ one year & 33 & $18.2 \%$ \\
\hline & $\geq 1-2$ years & 42 & $23.2 \%$ \\
\hline & $\geq 3-5$ years & 66 & $36.5 \%$ \\
\hline & $\geq 6$ - 10 years & 29 & $16 \%$ \\
\hline & $\geq$ ten years & 11 & $6.1 \%$ \\
\hline \multirow{5}{*}{ Education } & High School & 62 & $34.2 \%$ \\
\hline & Diploma & 88 & $48.6 \%$ \\
\hline & Bachelor & 21 & $11.6 \%$ \\
\hline & Master & 5 & $2.8 \%$ \\
\hline & Other Qualifications & 5 & $2.8 \%$ \\
\hline \multirow{2}{*}{ Sex } & Female & 128 & $70.7 \%$ \\
\hline & Male & 53 & $29.3 \%$ \\
\hline \multirow{5}{*}{ Age } & $\leq 25$ & 73 & $40.33 \%$ \\
\hline & $\geq 25-35$ & 73 & $40.33 \%$ \\
\hline & $\geq 36-45$ & 33 & $18.23 \%$ \\
\hline & $\geq 46-55$ & 2 & $1.11 \%$ \\
\hline & $\geq 55$ & 0 & $0 \%$ \\
\hline
\end{tabular}

Tabel 4. The Level of Employees Work Stress

\begin{tabular}{|c|c|c|c|}
\hline Working Division & $\begin{array}{l}\text { Job Stress } \\
\text {-Severity }\end{array}$ & $\begin{array}{c}\text { Job Pressure } \\
\text {-Severity }\end{array}$ & $\begin{array}{c}\text { Lack of Support - } \\
\text { Severity }\end{array}$ \\
\hline Medical Professional & 5.4 & 5.4 & 5.3 \\
\hline Medical Support & 4.7 & 5.0 & 4.5 \\
\hline \multirow[t]{2}{*}{ General Support } & 4.2 & 4.5 & 4.4 \\
\hline & $\begin{array}{l}\text { Job Stress - } \\
\text { Frequency }\end{array}$ & $\begin{array}{c}\text { Job Pressure - } \\
\text { Frequency }\end{array}$ & $\begin{array}{c}\text { Lack of Support - } \\
\text { Frequency }\end{array}$ \\
\hline Medical Professional & 3.4 & 3.5 & 3.2 \\
\hline Medical Support & 3.1 & 3.4 & 3.0 \\
\hline \multirow[t]{2}{*}{ General Support } & 2.4 & 2.8 & 2.3 \\
\hline & $\begin{array}{l}\text { Job Stress - } \\
\text { Index }\end{array}$ & $\begin{array}{l}\text { Job Pressure - } \\
\text { Index }\end{array}$ & $\begin{array}{c}\text { Lack of Support - } \\
\text { Index }\end{array}$ \\
\hline Medical Professional & 20.6 & 20.6 & 20.2 \\
\hline Medical Support & 17.9 & 18.9 & 15.4 \\
\hline General Support & 13.1 & 15.1 & 14 \\
\hline
\end{tabular}


Tabel 5. The Source and frequency of Stress

\begin{tabular}{ccc}
\hline Medical Professional & Medical Support & General Support \\
\hline $\begin{array}{c}\text { A personal insult from patients or co- } \\
\text { workers (JS-S5) }\end{array}$ & Severity & \\
\hline & Frequency & Unsatisfactory rewards (JS-S6) \\
\hline Overtime (JS-F2) & Lack of personnel (JS-F4) & Lack of personnel (JS-F4) \\
\hline
\end{tabular}

need to deliver health service to support medical treatment. They are employees in the laboratory, radiology, pharmacy, etc. If people in the medical division must have direct contact with the patients on a daily basis, employees in medical support do not have that requirement. This condition explains the lower level of stress in this division, because their work demand and time pressure are quite less in term of direct rapport with the patients, and they experience less emotional severe contagion.

The employees in general support are people with the lowest level of stress. This condition occurs because they work as supporting staffs in the hospital. They do not directly relate to the health service providing. They may experience emergency situation less frequent compared to employees in medical division. Most of them commonly work in a regular hour without night shift and their job responsibilities traditionally related with hospital management such as marketing, finance, and human resource.

Table 5 illustrates the source of stress severity based on 30 job stressors from JSS instrument. The employees in medical division confessed that the most severe cause of stress is a personal insult from patients or co-workers, while for employees in medical support the source of stress is related to unsatisfactory rewards. The most frequent stress event which occurs in the last six months is overtime for the majority of workers in the medical division; it happens at least four times while for employees in medical support and general support the lack of personnel is considered as the most frequent stress event occurred in the last six months. It happens five times on average in medical support division and three times in average in general support.

\section{MANAGERIAL IMPLICATION}

To test whether the severity of stress, the frequency of stress, and index of stress are experienced significantly different by the employees from those three divisions, the ANOVA test is performed. According to table 6 which summarise the result of ANOVA test, it indicates that the mean level of severity is less than 0.05 . It implies that the severity of stress is experienced differently by people from those three divisions and it confirmed that people who work in the medical division have the highest level of stress severity. However, the frequency of stress and index of stress are similar in all division except for job-stress sub-scale. It implies that in short, the incidence of stress is quite similar in all divisions. The job stressor event happens in all division repeatedly in the last six months range from three times to six times during the previous six months. This finding leads to the conclusion inspite the employees in hospital experienced the different level of severity in stress but because of their stress frequency is similar thus; in general, their stress index is also identical, whereas stress index is obtained from the multiplication of severity and frequency.

This study affirmed that work stress is prevalent among the employees who work in the hospital. The people in the medical division have a high level of severity in comparison to other divisions 
Tabel 6. ANOVA Test Result

\begin{tabular}{ccc}
\hline Job Stress - Severity & Job Pressure - Severity & Lack of Organizational Support - Severity \\
$0.000^{*}$ & $0.006^{*}$ & $0.007^{*}$ \\
\hline Job Stress - Frequency & Job Pressure - Frequency & Lack of Organizational Support - Frequency \\
$0.007^{*}$ & 0.094 & 0.054 \\
\hline Job Stress - Index & Job Pressure - Index & Lack of Organizational Support - Index \\
$0007^{*}$ & 0.113 & 0.098 \\
\hline
\end{tabular}

* Significant $<0.05$

since people in medical division are the key players in the hospital which make them take possession of tough responsibilities. However, in general, the work stress is experienced by all employees in the hospital in a similar pattern, it indicates from the stress index. Even though the severity level is high for workers in the medical division but because the frequency of stress is quite identical in all divisions it makes all the workers have equal stress exposure. The management must take preventive action to overcome this problem before it gets worse in the future. In stress index, the respondents in the study reported moderate stress index range from 13.1 to 20.6 in scale 0 to 81. The hospital must design stress management program to maintain stress level to ensure work stress does not impact to a negative manifestation. Moderate stress level is acceptable and sometime moderate stress is important because without stress work environment will less challenging, but a high level of stress is also not suitable for employees well being (Mohsin and Wahab, 2013; Parker, 2007). Organisation could formulate stess management programme focusing to (1) organisational approach such as redesigning jobs, improve organisational communication, and establish corporate wellness activities; and (2) individual approach such as creating social support system.

\section{CONCLUSION}

There are significantly different on severity level among medical professional, medical support, and general support divisions due to those three divisions have different nature of work. Every division experiences different job stress, job pressure, and lack of organisational support. However, the different level of frequency and stress index is insignificant among three divisions.

The result revealed that people who work in the medical division have a higher level of stress compare to other divisions. It is unsurprisingly since medical professionals are the key players in the health industry. In general, the work stress of employees in the hospital where research takes place classified as moderate. This condition must be maintained by the management by carrying out stress management program in the hospital to prevent work stress goes into a worse situation in the future. 
Agyemang, C.B., Nyanyofio, J.G., \& Gyamfi, G.D. (2014). Job Stress, Sector of Work, and Shift-Work Pattern as Correlates of Worker Health and Safety: A Study of a Manufacturing Company in Ghana. International Journal of Business and Management, 9(7), 59-69.

Azwar, A. (1996). Pengantar Administrasi Kesehatan. Edisi Kedua. Jakarta: PT. Bina Rupa Aksara.

Dewe, P.J., O'Driscoll, M.P., Cooper, C.L. (2012). Theories of Psychological Stress at Work. R.J. Gatchel and I.Z. Schultz (eds.), Handbook of Occupational Health and Wellness, Handbooks in Health, Work, and Disability. New York: Springer Science Business Media

Habibi, E., Dehghan, H., Safari, S., Mahaki, B., \& Hassanzadeh, A. (2014). Effects of work-related stress on work ability index among refinery workers. Journal of Education and Health Promotion, 7(1), 43-48.

Himabindu N., \& Syed, S.M. (2013). Stress Management In Sri Venkateswara Institute Of Medical Sciences Hospital, Tirupati, Andhra Pradesh. International Journal of Organizational Behaviour \& Management Perspectives, 2(1), 286-295.

Holmstrom, S., Molander, B., Jansson, J., \& Bergqvist, M.B. (2008). Evaluation of a Swedish version of the Job Stress Survey: Personality and Social Sciences. Scandinavian Journal of Psychology, 49, 277-286.

Hu, Y., Wang, D., Xu, G., \& Xu, P. (2014). The Relationship Between Work Stress And Mental Health In Medical Workers In East China. Social Behavior And Personality, 42(2), 237-244.

Ibrahim, H.I. (2014). The Relationship Between Job Stress, Co-Worker Support And Organization-Based Self-Esteem: A Survey Across Different Occupations. Journal of Arts, Science \& Commerce, 69-78.

Jannoo, Z., Yap, B. W., \& Haron, H. (2014). Evaluation of the job stress survey and its factor structure. Quality and Quantity, 49(2), 711-726.

Lu, L., Liu, L., Sui, G., \& Wang, L. (2015). The Associations of Job Stress and Organizational Identification with Job Satisfaction among Chinese Police Officers: The Mediating Role of Psychological Capital. International Journal of Environment Research Public Health, 12, 15088-15099.

Mohsin, S.F., \& Wahab, A. (2013). Stress Management and Steps of Managing Stress. Asia Pacific Journal of Management \& Entrepreneurship Research, 2(1), 164-172.

Nowrouzi, B., Lightfoot, N., Lariviere, M., Carter, L., Rukholm, E., Schinke, R., \& Gardner, D.B. (2015). Occupational Stress Management and Burnout Interventions in Nursing and Their Implications for Healthy Work Environments. Workplace Health \& Safety, 63(7), 308-315.

Obasohan, M.O., \& Ayodele, K.O. (2014). Assessment of Job Stress among Clinical Health Workers in Three Selected Healthcare Industries in Lagos State, Nigeria. Ife PsychologIA, 22(2), 58-63.

Parker, H. (2007). Stress Management. Delhi: Global Media.

Pisljar, T., Lippe T., \& Dulk, L. (2011). Health among hospital employees in Europe: A cross-national study of the impact of work stress and work control. Social Science \& Medicine, 72(6), 889-906.

Salilih, S.Z., \& Abajobir, A.A. (2014). Work-Related Stress and Associated Factors Among Nurses Working in Public Hospitals of Addis Ababa, Ethiopia: A Cross-sectional Study. Journal of Workplace Health \& Safety, 62(8), 326-332.

Sekaran, U. (2003). Research Methods For Business. United States of America: Southern Illinois University at Carbondale.

Thian, J.H.M., Kannusamy, P., Gu H. H., \& Yobas, P.K. (2015). Relationships among Stress, Positive Affectivity, and Work Engagement among Registered Nurses. Journal of Psychology, 6, 159-167. 